\title{
Caught between Two Worlds: A Non-Verbal Account of the Culture Shock in the First Bilateral "Exchanges" between France and the Joseon Kingdom (Korea)
}

\author{
Elena BUJA \\ Transilvania University of Braşov \\ Department of Theoretical and Applied Linguistics \\ elena_buja@yahoo.com
}

\begin{abstract}
International relations often cause culture shock not only for the foreigners visiting a country but also for the residents of that country. While nowadays this shock can be diminished by making people who move to another country become more aware of and understand the differences between cultures through all sorts of sources of information, this was not so easy at the end of the $19^{\text {th }}$ century.

In this paper, my intention is to bring to light the culture shock experienced by one of the first French persons to set foot in the Joseon Kingdom (current Korea) and by the first Korean woman who travelled to France at the turn of the $19^{\text {th }}$ century. I will investigate some non-verbal elements of culture, such as artefacts, food, and habits, which often make foreigners feel frustrated and confused, becoming incapable of interacting in a meaningful way in the new culture. The framework I will use is the "culture shock model" put forward by Oberg (1954), according to which this phenomenon unfolds in 4 stages: the "honeymoon", the crisis, the adjustment, and the adaptation. The data is provided by Kyung-Sook Shin's (2007) novel, Yi Jin, based on a true story (translated into Romanian as Dansul privighetorii de primăvară, 2017, Humanitas), from which I have excerpted the most relevant fragments regarding the topic.

The paper concludes with the idea that, at least in the time which creates the temporal backdrop of the investigated novel, the absence of intercultural encounters, the lack of solid information about each other's cultures as well as the different patterns of experience of the main characters lead to their estrangement.
\end{abstract}

Keywords: intercultural encounters, culture shock, French (Western) culture, Korean (Asian) culture, non-verbal elements 


\section{Introduction}

South Korea, a small Asian peninsular country, is nowadays one of the world's most technologically advanced nations, exporting goods and know-how to many western countries. Its current economic success is all the more amazing considering the historical events that affected the life of the people living on the peninsula in the $20^{\text {th }}$ century: the occupation by the Japanese troops (1910-1945), followed by the Korean War (1950-1953) and the viciously suppressed student uprising in Gwangju in 1980. Also worth mentioning is that Korea was a "hermit kingdom" until the end of the $19^{\text {th }}$ century in that it would not allow or encourage any political, commercial, or cultural exchange with the rest of the world. But, little by little, seeing that China and Japan, its powerful neighbours, were way ahead in this respect, the gates of the kingdom ${ }^{1}$ started to open at the turn of the century, and thus at present, South Korea has become a key player in economy and international politics. And the Korean influence in today's world does not stop here: the Korean cinema (especially the K-dramas), the performing arts (both traditional and contemporary), and the literature have enjoyed global recognition for their sophistication. All these products of the Korean culture are a reflection of its values, which are highly influenced by Confucianism and, at the same time, constitute a bridge between the Eastern and the Western worlds.

\section{Culture and culture shock}

Culture, being more than just a set of customs, constitutes the deposit of knowledge, experience, beliefs, values, attitudes, meanings, social hierarchies, religions, notions of time, roles, spatial relationships, concepts of the universe, and material objects and possessions acquired by a group of people in the course of generations through individual and group striving (Samovar-Porter 2003: 8).

This definition moves across a broad number of elements, from thoughts, values, and beliefs (elements that are very difficult for an outsider to perceive and understand) to material objects (that are easier to discover). When people belonging to different cultures cross the boundaries of their home countries, they take with them their cultural patterns. Crossing cultures can be both a blessing and a curse: on the one hand, it can be an interesting and rewarding experience as people come to see new places and witness new habits and behaviours. But, on the other hand, it could be equally stressful and bewildering as things that are totally different from your own culture tend to make you feel alienated.

Cultures can be closer or more distant with respect to their sociocultural values. Thus, the French and the British cultures would share most of these values. On

1 Between 1392 and 1897, Korea was known under the name of the Kingdom of Joseon Dynasty. 
the other hand, France and Korea would be culturally distant in terms of such key elements as language, religion, the status of women, attitudes to authority, or the legal system (Ward et al. 2001). Consequently, when the cultural gap between the interactants in cross-cultural communication is great, they will have more difficulty in adapting to the new environment, and there are higher chances that they would experience a culture shock. This concept, launched by Kalervo Oberg, is defined as a mental illness of the people who are transplanted abroad, "precipitated by the anxiety which results from losing all our familiar signs and symbols of social intercourse” (Oberg 1954: 1).

The individual reactions of people to culture shock and the circumstances that trigger this phenomenon depend on a variety of factors such as "previous experiences with other culture and cross-cultural adaptation; the degree of difference in one's own and the host culture; the degree of preparation; social support networks; and individual psychological characteristics" (FurnahmBochner 1986, qtd in Winkelman 1994: 121). At the same time, the symptoms of culture shock can vary from person to person. In an article published in 1960, Oberg mentions six main aspects of culture shock: strain caused by the effort to adapt, sense of loss and feelings of deprivation in relation to friends, status, profession, and possessions, feeling rejected by or rejecting members of the new culture, confusion in role, values and self-identity, anxiety and even disgust/ anger about "foreign" practices and feelings of helplessness, not being able to cope with the new environment. Oberg (1954) was also the one who developed a model of acculturation, the tenet of which is that crossing cultures puts people through a cycle of distinct phases on the way to final adaptation. These phases are briefly presented in what follows:

(a) In the honeymoon phase, "all encounters in the new place are seen as exciting, positive and stimulating. The new life is viewed as providing endless opportunities (...). There is openness and curiosity, combined with a readiness to accept whatever comes" (Marx 2001: 8).

(b) In the second phase, the crisis phase, culture shock sets in: the sojourners experience an “emotional 'down', a decreased sense of well-being” (Zapf 1991: 3). They show hostility towards the others, they feel discouraged, lonely, depressed, and permanently homesick, and tend to withdraw from social activities.

(c) The third stage, adaptation or recovery, brings with it a mild improvement of the foreigners' state of mind in that they start being able to interpret cultural clues, and they experience comfort with the new environment and a sense of belonging; they also acquire the ability to see things from the perspective of host nationals. There are, nevertheless, cases in which foreigners fail to find resolution for the problems they were confronted with in the culture shock phase, and, consequently, they will continue struggling with a feeling of frustration and eventually will decide to leave the host country. 
(d) The last phase, full recovery, "is achieved as one develops stable adaptations in being successful at resolving problems and managing the new culture" (Winkelman 1994: 122). In a way, we may say that these sojourners are on their way of becoming bicultural.

What is worth mentioning is the fact that if the persons who have become bicultural return to their original culture they will go through the abovementioned stages again, especially if their stay in the foreign country was quite long.

\section{Research methodology}

As one of the characters (Hong Jong-u) in the novel suggested, "the fastest way to make one's culture known by other nations is to give them the opportunity to read Korean literature in their own languages" (Shin 2017: 226). Shin's novel, Yi Jin (2007) - translated into Romanian under the title Dansul privighetorii de primăvară (2017) - proved a goldmine of information about the Korean culture in general and the culture shock experienced by its main characters in particular. Though a work of fiction, it is based on real facts, which are well documented. The novel depicts the deep love between one of the first French consuls, Victor Collin de Plancy, at the court of the Korean emperor and Yi Jin, the first Korean woman who set foot in France at the end of the $19^{\text {th }}$ century. Their first encounter occurs within the premises of the imperial palace in Seoul; their love affair continues in Paris for three years only to end tragically back in Korea. Since the heroes come from totally different cultures, each of them experienced culture shock in the country of the other, and therefore the end of their relationship does not really come as a surprise.

The research questions that I seek to find answers to are the following:

(1) Do both characters follow the same stages/phases of culture shock?

(2) Are the effects of culture shock similar for Victor and Yi Jin?

(3) Which particular non-verbal elements caused the culture shock?

(4) Could their relationship have been saved provided they had a deeper knowledge and understanding of the other's culture?

In order to offer as clear an image as possible of the acculturation process of Victor and his Korean lover, I have excerpted from the above-mentioned novel those fragments that reflect their states of mind and the factors that triggered them along the story line. 


\section{Analysis}

The aim of my analysis is to see how the two characters of the novel interacted with two cultures and how the culture change process unfolded for and affected each of them. The narrative analysis method proved useful in this respect since narratives, as forms of discourse, contain events and happenings that succeed in a certain order, forming the plot, and "describe when and why certain events and actions took place and what intended results of the actions were" (Pak 2006: 45). This method proved useful in revealing how the acculturation process unfolded temporally for each of the two characters.

In what follows, I shall trace the culture change process of Victor and Yi Jin along the stages proposed by Oberg (1954), in an attempt to reveal the complexity of their individual cases, supporting the changes in each phase with excerpts from Shin's novel.

\subsection{The pre-departure phase ${ }^{2}$}

It is worth mentioning that despite the few sources of information that were available for people at the end of the $19^{\text {th }}$ century, both Victor and Yi Jin, when confronted with the prospect of visiting a foreign country, tried to find out something about the other's culture prior to crossing the boundaries of their own countries. Thus, as a diplomat, Victor had the chance of getting familiar with the Chinese culture, which is not very different from the Korean one. Then, he also tried to become familiar with the Korean court etiquette so as not to make any blunders when meeting the royal family. For example, he learned that he was supposed to bow in front of the emperor and not shake hands with him, as it was customary in the Western world, or that when leaving the emperor he was not supposed to turn his back to him, and so he retreated facing the royal figure (p. 82). ${ }^{3}$ Also, when he presented the imperial couple with presents (Sévres porcelain objects) sent by the French government, he wrapped them in red silk, as was required by the palace etiquette:

(1) Victor untied the silk wrapping. He had heard that in Korea red was the royal colour; this was why he did his best to find red silk. (p. 98)

Wrapping cloths (known in Korean as bojagi) were of various shapes, sizes, and colours and were used for wrapping almost anything. "By wrapping an object,

2 I consider that preparation for a future cultural experience could be part of the acculturation process. This is why I have introduced this subsection, as it is relevant for what follows.

3 For the sake of simplicity, quotations from the novel will carry only the page number from which they have been excerpted. They are translated from Romanian into English by myself. 
the user hoped to trap happiness or blessings in the folds of the cloth" (Teacher's n.d., p. 11). However, while for the commoners this type of cloth was produced from fabric scraps that were beautifully assembled into a patchwork design by ordinary women for whom every bit of cloth was precious, for the royalties the wrapping cloth was supposed to be made of one piece of red silk.

Victor also learned about the Korean customs from the mistakes made by previous diplomats in Korea; so, he prepared thoroughly for his first encounter with the king. He dressed properly (not in evening clothes, like the English consul, but in his uniform) and "arrived at the palace one hour before the meeting" (p. 73). He also searched for information about the dances performed at the Korean palace "as he hoped that one day he would have the chance to watch such a performance, and his nature urged him to be always prepared for what was to follow" (pp. 101-102).

Yi Jin, in her turn, learned French from Father Blanc, a French Catholic priest who was a missionary in Korea and who was convinced that "in the future, the Joseon Kingdom will witness a development that we can hardly suspect at the moment. It is always useful to know something that others don't” (p. 57). That is why he did his best to teach Yi Jin his mother tongue. Knowing the French language, Yi Jin starts reading about France, about its citizens and its president, finding it very odd that this country has a president and not a king as a ruler (p. 19). As she spends some months at the French legation in Seoul, where she has a huge library at her disposal, she begins to read French literature in the original, her favourite book being Victor Hugo's Les Miserables. In this endeavour, she is encouraged by her empress, who is extremely curious about the Western culture: "the foreigners' habits, their way of grooming, their eating habits, cooking recipes and education" (p. 22).

Still, the information acquired about the other's culture was not sufficient for them to get fully acquainted with it, and so both characters experience excitement and sometimes numbness when exposed to the host culture, as we shall see in section 4.2. Though Yi Jin was eager to see France, the distant country that took two months on sea to reach, she was dominated by the fear of the unknown and by the sorrow of having to leave the dear ones behind, not knowing whether she would ever return to Korea. Victor, on the other hand, did not exhibit any of these negative states.

\subsection{The honeymoon phase}

Yi Jin's first contact with the Western world occurred in Korea, when the empress sent her to spend some time at the French legation for fear the king might fall in love with her. Her astonishment at seeing the building of the legation is reflected in the following excerpt: 
(2) It was for the first time that she saw a building with tiles and glass windows and a petrol lamp, like the one in the middle of the courtyard (...). Under the eaves, there were some chairs, which seemed to have been brought from France. All windows had glass panes and curtains. (p. 123)

Yi Jin's astonishment is caused by the difference between the Korean architecture and the French one. In Korea, the houses of the ordinary people at the end of the $19^{\text {th }}$ century had roofs made of straw thatch, while the "window and door panels were covered with white rice paper instead of glass" (Clark 2000: 93). Moreover, they were built above the ground level, in an L-shape, the windows facing the inner yard, assuring in this way privacy and security.

The astonishment increases when she reaches Paris, where the two- or threestorey houses as well as the numerous means of transport leave her in awe. Once, when Victor took her to the island on the Seine and they reached the Notre-Dame Cathedral, she stopped in front of it.

(3) She could not believe that a building like that, with its refined and impressive Gothic architecture, was made by man. (...) For a long time, Jin's eyes were stuck on the towers that rose to the sky and on the statues that were looking at the crowd below. (p. 229)

In one of the letters that Jin wrote to her Korean empress, she confessed that what astonished her most were the means of transport. From among them, she considered the train to be the most impressive of all, followed by the merchant ships with propellers and the tram, which she described as "a big coach, propelled by steam, just like a steam engine" (p. 231). She was impressed by the network of trams (covering 25 lines at the end of the $19^{\text {th }}$ century) and by the horse-drawn coaches of various shapes and colours, each colour indicating a certain route. In comparison to France, transport in Korea was rather primitive in those days: noblemen would be carried in palanquins, while commoners would walk or ride horses and use carts if they had to cover longer distances as there were no trains. Later on, in another letter, Yi Jin informs the empress about another artefact - the airplane -, an invention of two German brothers by means of which the distance between Europe and Joseon Kingdom could be covered in two or three days. We can imagine the heroine's surprise at seeing all those modern discoveries that made the life of the Europeans much easier and more pleasant than that of the Koreans. She was like a child who discovered new and beautiful toys.

What I consider most important for Yi Jin in her honeymoon phase were the liberty she enjoyed and the books she could read. In Korea, there was a law according to which any female who became a maid at the imperial palace was not allowed to marry, irrespective of what she chose to do after leaving the Court. Nor 
was she allowed to marry in case she was expelled from the Court. If she broke the law, she was severely punished. She had to be subservient to the imperial couple, to the other wives of the king, ${ }^{4}$ and to all the persons who enjoyed a higher status or were older. This submissiveness was dictated by the Confucian hierarchical social structure. ${ }^{5}$ In the turn-of-the-century France, women enjoyed more freedom: they could go out unaccompanied by men, they could go shopping or to cafés with other female friends, or they could visit museums without breaking any rules or being gossiped about. Coming from a culture where she was kept like a beautiful bird in a birdcage, Yi Jin cherishes the freedom to be herself and to do what her French female counterparts did. This emerges from the letters she wrote to the empress. While in the beginning she would refer to herself as "my humble being" and would write the letters with a brush, as was customary in Korea, in time she would use the personal pronoun "I" and would employ either a pen with a nib or a fountain pen, which was non-existent in Korea at the end of the $19^{\text {th }}$ century.

(4) She realized she had used "I" instead of "my humble person" throughout the letter. She thought for a while, adjusted the nib of her pen, but did not change anything in the letter. (p. 206)

Also from a letter addressed to the Korean empress, we apprehend Yi Jin's joy for reading and her enthusiasm at discovering new things about distant countries from the books:

(5) What can I compare the joy of reading with? Books from all over the world are translated into French, being available for anyone. They bring new elements of culture and civilization, which intertwine with the traditional ones. I envy the French writers, who can write naturally and freely in their own mother tongue. (p. 278)

Back home, in Korea, the range of authors available to the readers was rather limited in that they were mainly Chinese, "one's education being limited to the Confucian classics" (Kohls 2001: 139), and - as we can assume from the excerpt above - the topics were not as varied or enjoyable as the ones belonging to universal literature.

4 Plural marriage was common in Korea until the end of the $19^{\text {th }}$ century. There was, nevertheless, a difference between the primary wives, who came from certified élite families, and the secondary wives, who were commoners or even slaves (Deuchler 2003).

5 The Confucianists of the Joeson Dynasty "restricted the freedom of women to travel and move about. Upper-class women were ordered not to go out during the daytime” (Clark 2000: 164). 
Victor's "honeymoon" phase was much shorter than Yi Jin's and is related to the discovery of Yi Jin. The first relevant fragment from the novel that reveals his positive feelings towards the Koreans is when he first met Yi Jin at the palace:

(6) The girl's dark and deep eyes were watching him with unbelievable tenderness. It was for the first time in Korea when somebody looked at him in a friendly way, without any trace of rejection or amazement or naive curiosity. (p. 76)

Not only did Yi Jin regard Victor with tenderness, but she also greeted him in French, which impressed him even more. Then, at the event organized by the imperial couple for the foreign diplomats, Victor experiences a second surprise on behalf of Yi Jin:

(7) After having finished her song, the dancer turned her head sideways, performing an ample movement with her arms. In that moment, Victor, who was on the point of sipping the wine from his glass, remained dumbfounded. For a moment, he caught the dancer's eyes. He was eagerly waiting for the next moment when their eyes would meet again. (...) Victor could not keep his eyes away from her. (...) It was her! (p. 103)

\subsection{Culture shock}

In intercultural communication, people come with different cultural backgrounds, experiences, and expectations. When confronted with cultural practices and habits that are different from their own, they either re-evaluate their cultural background for the sake of adapting to the new environment, or they start questioning their cultural education and suffer a culture shock. Our heroine, Yi Jin, "[j]uggling two very different cultures and social situations" (Pak 2006: 37), had to face fast changes, contradictions, and ambiguities in her life, which brought about the culture shock.

\section{- Hugging/kissing}

While in the pre-honeymoon phase, certain behaviours foretold of Yi Jin's emergent culture shock. Thus, when she came to visit Victor at the French legation in Seoul, she was perplexed by his behaviour:

(8) Without thinking, Victor hugged and kissed her warmly on her cheek. Everything happened so fast that Jin had no time to react. She remained dumbfounded and looked at him with consternation. (p. 119) 
Seeing the girl's horror on her face, Victor realized that he had made a blunder by behaving as if he were in France, where kissing and hugging were very common when greeting friends. No matter how hard he tried to explain to her that this behaviour stemmed from the fact that he perceived her as an old acquaintance, she could not easily overcome her embarrassment and overcome the cold look. Her shock is explained by the fact that the Korean society is a non-haptic one: touching behaviour should be refrained from, more so when the persons are of different sexes and especially if the woman is a servant of the palace. According to the Korean law, "even the members of the royal family are punished if they touch a court maid/servant” (p. 356).

\section{- Stares/gazes}

An important contribution to Yi Jin's culture shock had the gazes and stares she received both from her compatriots and from the French people. These started in Korea, while she would walk with Victor on the streets in the neighbourhood of the French legation. Since mixed-race couples were unheard of and unaccepted by the Koreans of the $19^{\text {th }}$ century, there is no wonder that people watched them disapprovingly, especially when Yi Jin started wearing Western dresses. Once she set foot in France, Yi Jin became a curiosity for the Parisians both due to her looks and to her fluency in their mother tongue. In the beginning, she did not have the time to mind the curious looks of the French people as she was eager to discover France and Paris. She was impressed by everything that was new to her. But little by little these glances ended up bothering her, even hurting her, making her feel like an exhibit in a museum or like an animal in the zoo. They also made her think of how Victor must have felt in Korea, when he himself was a curiosity for the Koreans.

(9) An elderly lady of noble birth, who was walking slowly, followed by her servant, was just staring at her. The servant (...) was doing exactly the same.

Some clowns, who were probably preparing for a performance on the bridge, glanced at her as she passed by. A boy who was running on the bridge slowed down when he reached them and, after studying Jin with blunt curiosity, smiled broadly, with satisfaction. (pp. 252-253)

Victor himself experienced a state of unease when he paid the first visit to the Korean palace as the young female servants who were scurrying from one building to another pulled a long face when setting eyes on him. "They were stunned to see a stranger with brown hair and white face. His uniform was something awesome, never seen before" (p. 75). As Korea was isolated from the rest of the world, the 
people of the kingdom did not have the chance to encounter persons of other races, and so seeing someone who was physically different from the Asians came as a shock for the girls, while their reaction caused embarrassment in Victor.

\section{- The graves/tombs}

On the way from Jemulpo to Seoul, where Victor was to encounter the king, he caught sight of some round mounds.

(10) Not knowing what they were, he was intrigued in the beginning by these earth elevations, covered with grass, which emerged not only on hill slopes, but also that these were tombs. (...) Victor felt somewhat embarrassed. So, this is the way the Koreans prepared the places for the afterlife: round, simple, and green. (p. 74)

The reason why these burial mounds were so scattered across the Korean landscape was the Korean's belief that "to fail to choose the proper place for a loved one's grave will cause the living heirs to have bad luck" (Kohls 2001: 226). That is why they would make use of the advice of a geomancer to select a lucky spot to bury their deceased people. And each of these specialists had a different opinion about where the graves should be situated, as long as it was a sunny place. Due to the fact that the graves did not present any tombstones or flowers, like the Western graveyards, it was natural for Victor to experience disorientation.

On the other hand, while in France, Yi Jin went through the same shock when she found out that a place, which, to her, looked like a garden or a park, was actually a cemetery:

(11) When she first saw this place, Jin was convinced that it was a park as she saw a boy with a cape and a beret, playing there with a hoop. Her presupposition was confirmed by the presence of his mother, seated on a bench, with a book on her knees, in the shade of her umbrella. When Victor explained to her that it was a graveyard, she was very surprised. She believed him only when he showed her the old tombstones, hidden by tall grass and trees. (p. 302)

\section{- Habits}

Little by little, Yi Jin starts missing the food she used to eat in Korea as well as the Korean eating and sleeping habits. To her, the sound of the fork placed on the plate was so loud as compared to the sound produced by the chopsticks that she could hardly bear it. Despite the comfort of the bed in Paris, Jin preferred to sleep 
on the floor, as she used to do at home. But while the Korean floors were heated through a system called ondol, "which gave Koreans radiant heating as early as the seventeenth century" (Kohls 2001: 2019), the French ones were very cold.

(12) [...] She would often lie down on the floor, near the bed, after Victor fell asleep. Then, in the morning, she would climb into the bed before he woke up. (p. 230)

\section{- The morgues}

A weekend pastime of the Parisians, which seemed to be a major attraction for them at the end of the $19^{\text {th }}$ century and which Yi Jin found appalling, was visiting the morgues. There were a couple of such places in Paris, one of them being situated right behind the Notre-Dame Cathedral, where the bodies of unknown deceased persons were exhibited behind windows:

(13) [...] Jin noticed a long line of people. They were the visitors of the morgue, who wanted to see the corpses shown behind windows (p. 229). Since she left Korea, she has seen many new things, but it was for the first time that she saw a corpse exhibition. The crowd was gathering especially in front of the corpses of two sisters, who had been taken out of the river. (p. 243)

The shock of seeing the corpses was so strong for Yi Jin that she ran away, feeling sick. It also made her wonder why the Parisians were so attracted by such a gruesome sight when there were so many beautiful places to visit in the city. Cognitively and perceptually, this experience proved very bizarre to Jin, and it took her some time to figure out her feelings about the French people's attitudes towards the dead. She perceived this exhibition of corpses as lack of respect for one's ancestors, which was in stark contradiction with the Korean ancestral rites.

\section{- Prejudices}

Stereotypes are another factor that could trigger culture shock. One aspect that caused Yi Jin's loss of self-confidence was the French people's prejudices concerning Korean court dancers. In one event attended by lots of Parisian personalities, Yi Jin was introduced to the famous writer Guy de Maupassant by one member of Victor's entourage, Mister Plancard. When the latter mentioned the fact that in Korea Jin used to be a court dancer, rumours started to circulate in the audience, which made her feel embarrassed. This was because in France female dancers who entertained people usually danced the can-can, which the 
respectable society considered to be extremely immoral due to the fact that the dancers showed their underwear. In stark contrast, Korean court dances were not meant for everyone. The dancers were selected from among the court maids who "learned the Court habits and etiquette, learned to sing and dance, studied medical practices, the Confucianist teachings, and the Korean alphabet” (p. 75). Those who proved gifted in dancing were trained at the Royal Dance Academy, and it was only the best who were selected to perform in front of the empress and the emperor, and Yi Jin was the Court's best dancer. Moreover, in comparison to the can-can, the dance which was famous in France at the end of the $19^{\text {th }}$ century and which involved rapid movements, the Korean court dances were more elaborate and very slow.

(14) Maintaining a certain posture for as long as it was necessary could be attained not by straining your muscles but by relaxing them. The breath needed to be controlled so as to be able to flutter like a butterfly, to take wing like a bird, to float like the air, and to gently settle down on the ground like a water flow. (p. 239)

Victor, in his turn, also had to face Korean prejudices, but they did not have such a strong impact on him as they were of a different nature. Being a keen photographer and having bought from France a small camera, when he reached the Joseon Kingdom, he wanted to take photos of the people. Much to his disappointment, he was denied this favour on the grounds of that "photographs would steal the man's soul" (p. 81). Even when the Korean emperor accepted to be photographed by the French consul, his courtiers were against it, invoking the same reason.

\subsection{Adaptation (adjustment)}

"Adaptation (...) comes in the form of learning the culture-specific skills that are required to negotiate the new cultural milieu (Bochner 1972, qtd in MasgoretWard 2016: 58). In this phase of acculturation, the sojourners may understand that cultural differences "can be justified from the other culture's perspective. [...] Differences become believable and acceptable" (Bennett 1986, qtd in ChenStarosta 2003: 346). If foreigners make an effort to understand these cultural differences, they have chances of adjusting to the host culture.

As far as our heroes are concerned, what is relevant for this phase is that they tried to help each other cope with the foreign culture. Thus, Victor taught his wife how to use the cutlery and the order in which to approach the food items characteristic of the western part of the world: 
(15) Victor would be the first to taste the soup and to spread the butter on the slice of bread with the knife; when the cook brought the chicken prepared in the French style, he would be the first to eat it by means of fork and knife. He thought that Jin was not familiar with eating like this. The latter would peek at him and eat the soup with a spoon and the salad with the fork. (p. 132)

On the other hand, when Victor was asked by his friends, who saw his vast collection of Asian artefacts, about the symbolism of the shapes and colours, Jin would provide help for him.

(16) She would explain the symbols of the images painted on the screens, the symbols of the flowers and birds painted on the vases, the manner in which they handled the brushes for writing and how they prepared the ink, or she deciphered for them the meaning of the Chinese script in various books. (p. 237)

Thus, the phoenix bird, which lived in the maple tree, appears only in times of peace; the ones who see it are said to be immortal (p. 20). The dragon is a symbol associated with water that ensures fertility, plenitude, and rejuvenation. The golden dragon came to be the symbol of the emperor while the phoenix of the empress. From among the flowers, the wild orchid (p. 16) is the symbol of spring, the peony symbolizes beauty, while the lotus flower is the symbol of purity (p. 19).

In what concerns this phase of the culture change process, there is a striking difference between the two main characters of the novel in that adaptation to the Korean habits, way of thinking, and behaving comes easier for Victor as compared to Yi Jin's adaptation to the Western way of life. This may be due to his shorter stay in Korea, to the fact that he was a man and a member of the diplomatic corps, was respected by the Koreans, and especially because he had already had some exposure to the Asian culture prior to his arrival in the Joseon Kingdom. For Yi Jin, the barriers to adaptation are more numerous and with a deeper impact.

\subsection{Re-construction and recovery}

As far as the last stage of the culture shock process (/cycle) is concerned, this is totally different for the two characters. For Victor, his stay in Korea made him explore and accept certain things which he found mind-boggling in the beginning. He learned to deal with the differences, to appreciate those aspects he perceived to be good and beautiful, and to disregard those that could have affected his well-being. For Yi Jin, on the other hand, all the differences which she 
originally found interesting and appealing came to deepen her inner crises. This was enhanced by her personal misfortunes (her husband's gradual estrangement, the loss of her unborn baby, her rejection by Victor's mother) and her longing for her homeland, for her beloved empress and friends. Rather than prolonging her unhappiness in France, Yi Jin decides to return to Korea, apparently on a short visit, accompanied by Victor. But the letter she sent Victor after his departure from Korea demonstrates that her decision to put an end to her foreign experience had been taken before they embarked for her homeland:

(17) Do you remember the perfumed satchel I had left between the pages of Les Miserables? (...) I left it on the Korean chest of drawers in the Asian room. (p. 314)

It was by means of this satchel that Yi Jin consented to become Victor's woman in Korea. Now, the same object came to be regarded as her non-verbal message that their relationship was over, as she placed in it the engagement ring received from Victor.

The same letter captures Jin's whole acculturation process from ecstasy to agony:

(18) In your country, I lived happily and I was "I", not "my humble person". Even if I forget the Eiffel Tower or the Louvre Museum, I will never forget how free and full of life the Parisians were. (...) I had lived at the palace since I was a child. To tear myself apart from those things that kept me thwarted and to be able to be myself was an amazing but at the same time frightening and painful experience, to the point of agony. (p. 351)

Once back in her homeland, Yi Jin hoped to find her inner peace, to reconnect with her old friends and, more than anything, to be accepted by her beloved empress. Much to her disappointment, her hopes and dreams are quickly crushed: the political situation she finds in Korea is disastrous: life at court abounds in betrayal, jealousy, and intrigue, culminating with the tragic assassination of the empress. On the other hand, due to her French clothes, hair-style, and habits, she feels an alien in her own country.

(19) Jin was used to the curious glances, but when even a Korean mother, who was suckling her infant on the porch of the inn, looked at her as if she were a foreigner, she was overwhelmed with pain. It was then that she realized that she had become an exhibit in her own country, as she used to be in France, too. (p. 315). 
Not being able to suffer any longer, Yi Jin, caught between two worlds and belonging to none, commits suicide.

\section{Discussion and conclusions}

Of the reasons for Yi Jin's inadaptation to the Western culture, we can mention the deep-seated cultural conflict. She was confused and often frustrated in dealing with contradictory values and the roles she had in her life (maid of the Korean Empress, which implied complete submission, and wife of a Western "husband", 6 which granted her a liberty undreamed of). She had to cope with the tension of holding onto two incompatible worlds of values, attitudes, and gender role expectations. Though apparently she managed to function properly in both cultures (as she did her best to get familiar with the Western world, being occasionally helped by Victor), at a deeper level, she felt uneasy at being the "other" in either culture as she was not French enough for mainstream France and, after returning to her home country, not genuinely Korean any longer for her compatriots (as she kept wearing European clothes, arranged her hair in the French fashion, and adopted French habits). Moreover, she also had to cope with the idea that in Korea she had to deal with a certain status, defined as "the experiences as a member of a minority group with lower status and power" (Pak 2006: 14), i.e. being a woman and a maid at the royal court, which changed in France, where she was exposed to more egalitarian values. But here she faced another problem, namely that of belonging to another race. Yi Jin was a member of the less desired gender in Korea (due to Confucianism, which preached male superiority and precedence over women), while in France she was a person of the less desired race, having a different skin colour, hair texture, and physiognomy.

We could say that more than Victor, Yi Jin is caught between two worlds, fighting against two forces: on the one hand, she is torn between "(1) acculturation - a force that propels individuals to new roots or the acquisition of the new host society's cultural traits and (2) ethnic identification - a force that binds individuals to their old roots or the maintenance of the original heritage culture" (Keefe-Padilla, 1987, paraphrased in Pak 2006: 18).

Realizing that she was a marginal person caught between two worlds and not entirely belonging to either and having gone through a number of historical and personal misfortunes that shattered her life (the loss of her unborn child, Victor's

$6 \quad$ Though Victor would introduce Yi Jin as his wife to his friends, he did not actually keep his promise to legally marry her once they arrived in Paris because his mother could not put up with the idea of having an Asian daughter-in-law, which shows that even Western people were prejudiced. She suspected that this was the reason why Victor kept silent concerning the marriage topic, but she never brought it up. Still, this was another factor that contributed greatly to the culture shock she suffered. 
estrangement, and the murder of her beloved empress as well as of her best friend), Yi Jin finally commits suicide.

Culture shock is the frustrating or negative stage in the process of adapting to a new culture. For Victor, it proved to contribute to his personal growth through adjustment and discovery of new worldviews. For Yi Jin, on the other hand, it had a devastating effect: despite her desire to please her empress with information about the new world (i.e. France) which the latter was incapable of seeing, despite her profound love for Victor and her wish to be a perfect European wife, the values of the Korean culture were too deep and impossible to discard. She permanently longed to be back in Korea, close to the empress she worshipped, to sleep on the heated Korean floor, to eat the Korean dishes, and to be looked at with admiration, not with curiosity.

To answer the last research question, it is hard to say whether, if Victor and Yi Jin had lived in the present day, their love story would have had a happy ending as even nowadays, despite the rich sources of information on various cultures and despite the globalization process, inter-racial/intercultural marriages may not be very successful. The last letter that Yi Jin wrote to Victor contains a line that accounts for the insurmountable cultural differences in such couples:

(20) Somehow, in my mind, you were France and I was Korea, when actually we should have been only a man and a woman. (p. 352)

\section{References}

Chen, Guo-Ming-Starosta, William. 2003. A review of the concept of intercultural awareness. In: Samovar, Larry-Richard E. Porter (eds), Intercultural communication. A reader. Belmont, CA: Wadsworth. 344-353.

Clark, Donald. 2000. Culture and customs of Korea. London: Greenwood Press. Deuchler, Martina. 2003. Propagating female virtues in Choson Korea. In: Ko, Dorothy-Jahyou Kim Haboush-Joan R. Piggott (eds), Women and Confucian cultures in premodern China, Korea, and Japan. Berkeley, London: University of California Press. 142-169.

Kohls, L. Robert. 2001. Learning to think Korean: A Guide to living and working in Korea. Yarmouth (USA): Intercultural Press.

Marx, Elisabeth. 1999. Breaking through culture shock: What you need to succeed in international business. London: Nicholas Brealey Publishing Limited.

Oberg, Kalervo. 1960. Culture shock: Adjustment to new cultural environments. Practical Anthropology 7: 177-182.

Pak, Jenny Hyung Chung. 2006. Korean American women. Stories of acculturation and changing selves. New York-London: Routledge. 
Shin, Kyung-Sook. 2007-2017. Dansul privighetorii de primăvară. (Transl. by Diana Yuksel. Bucharest: Editura Humanitas).

Ward, Colleen-Bochner, Stepehn-Furnahm, Adrian. 2001. The psychology of culture shock. East Sussex: Routledge.

Winkelman, Michael. 1994. Culture shock and adaptation. Journal of Counseling and Development 73(2): 121-126.

Zapf, Michael Kim. 1991. Cross-cultural transitions and wellness: Dealing with culture shock. International Journal for the Advancement of Counselling 14: 105-110.

\section{Web Sources}

Masogret, Anne-Marie-Ward, Colleen. 2016. Culture learning approach to acculturation. In: Sam, David L.-John W. Berry (eds), The Cambridge handbook of acculturation psychology, 58-77. https://www.cambridge. org/core/books/cambridge-handbook-of-acculturation-psychology/ BC73427826525962C01C7D00ECFEA362 (downloaded on: 3 February 2019).

Oberg, Kalervo. 1954. Culture shock. http://citeseerx.ist.psu.edu/viewdoc/dow nload?doi=10.1.1.461.5459\&rep=rep1\&type=pdf (downloaded on: 3 February 2019).

Teacher's (n.d.) A Teacher's sourcebook for Korean art and culture. https://sites. evergreen.edu/essentialingredients/wp-content/uploads/sites/182/2016/03/ korea-tsb1.pdf (downloaded on: 4 February 2019). 